\title{
Parasitological and molecular detection of Babesia canis vogeli in dogs of Recife, Pernambuco and evaluation of risk factors associated
}

\section{Detecção parasitológica e molecular da Babesia canis vogeli em cães de Recife, Pernambuco e avaliação de fatores de risco associados}

\author{
Vanessa Carla Lima da Silva ${ }^{1 *}$; Evilda Rodrigues de Lima ${ }^{2}$; \\ Mirella Bezerra de Melo Colaço Dias ${ }^{3}$; Fernanda Lúcia Passos Fukahori; \\ Michelle Suassuna de Azevedo Rêgo ${ }^{3}$; José Wilton Pinheiro Júnior ${ }^{4}$; \\ Pomy de Cássia Peixoto Kim ${ }^{5}$; Renata Serpa Cordeiro Sá Leitão; \\ Rinaldo Aparecido Mota $^{7}$; Elisa Paula de Oliveira Carieli ${ }^{8}$
}

\begin{abstract}
This work aims to detect the presence of Babesia canis vogeli in dogs from Recife, Pernambuco via molecular and parasitological detection methods, and to assess the risk factors associated with this parasite. A total of $146 \mathrm{dogs}$ (male and female) of varying breeds and ages that presented clinical symptoms of babesiosis were assessed at a clinical care center in the Veterinary School Hospital. Blood was obtained via venopuncture for hemoparasite detection and polymerase chain reaction (PCR). Using a commercial kit, DNA was extracted from blood samples. For the PCR reaction, an approximately 590 base pair long genetic sequence was used to detect the presence of $B$. canis vogeli. The forward primer, denoted as BAB1 (5'-GTG AAC CTT ATC ACT TAA AGG-3'), was specific for a conserved region on the 18S rRNA gene of Babesia spp., and the antisense primer was denoted as BAB4 (5'-CAA CTC CTC CAC GCA ATC G-3'). PCR results suggested that the percentage of Babesia canis vogeli infection was $4.8 \%$. Through descriptive statistical analysis of the data, we observed that there was higher frequency of parasite infection associated with male dogs above two years of age, with a defined breed, from the countryside, are domiciled, and also suffer from tick infestation. We conclude that regardless of the type of risk factor, babesiosis can be found throughout Recife, Pernambuco, and its prevalence does not vary in most regions of Brazil. Our results indicate that PCR is a sensitive test for the detection of blood parasites, and should be performed as a clinical routine.
\end{abstract}

Key words: Babesiosis, dogs, molecular diagnosis, infection

1 Dra ${ }^{\mathrm{a}}$, Médica Veterinária autônoma, Clínica Veterinária Pet Dream, Recife, PE, Brasil. E-mail: vcls2004@yahoo.com.br

2 Prof $^{a}$ Titular, Semiologia Veterinária, Dept ${ }^{\circ}$ de Medicina Veterinária, Universidade Federal Rural de Pernambuco, UFRPE, Recife, PE, Brasil. Email: evilda17@hotmail.com

3 Discentes do Curso de Doutorado do Programa de Pós-Graduação em Ciência Veterinária, UFRPE, Recife, PE, Brasil. E-mail: mirella_colaco@yahoo.com.br; fukahorifvet@hotmail.com; michellesuassuna@hotmail.com

4 Prof. Adjunto, Doenças Bacterianas dos Animais Domésticos, Dept ${ }^{\circ}$ de Medicina Veterinária, UFRPE, Recife, PE, Brasil. E-mail: wiltonjrufrpe@gmail.com

5 Discente do Curso de Doutorado do Programa de Pós-Graduação em Ciência Animal Tropical, UFRPE, Recife, PE, Brasil. E-mail: kim_pomy@hotmail.com

6 Me, Médica Veterinária autônoma, Prefeitura de Abreu e Lima, PE, Recife, PE, Brasil. E-mail: serpavet@yahoo.com.br

7 Prof. Titular de Doenças Bacterianas dos Animais Domésticos, Dept ${ }^{\circ}$ de Medicina Veterinária, UFRPE, Recife, PE, Brasil. E-mail: rinaldo.mota@hotmail.com

8 Médica Veterinária autônoma, Pet Shop Estilo Rural, Olinda, PE, Brasil. E-mail: isacarieli@gmail.com

* Author for correspondence 


\title{
Resumo
}

\begin{abstract}
Objetivou-se determinar a ocorrência da Babesia canis vogeli através da detecção molecular e parasitológica em cães de Recife, Pernambuco e avaliar os fatores de risco associados. Foram atendidos 146 cães de ambos os sexos, variadas raças e idades que apresentaram sinais clínicos sugestivos de babesiose provenientes dos atendimentos clínicos de um Hospital Escola Veterinário. O sangue foi obtido através de venopunção para a realização da pesquisa de hemoparasitas e da reação em cadeia pela polimerase (PCR). O DNA foi extraído de cada amostra a partir de uma alíquota de $200 \mu l$ de sangue com anticoagulante, utilizando-se o kit comercial. Para a reação da B. canis vogeli, foram utilizados oligonucleotídeos iniciadores que amplificam aproximadamente 590 pares de base. Os primers, BAB1 (5'-GTG AAC CTT ATC ACT TAA AGG-3') são específicos para uma região conservada do gene $18 \mathrm{~S}$ rRNA de Babesia spp., e o anti-senso BAB4 (5'-CAA CTC CTC CAC GCA ATC G-3'). O porcentual de infecção foi de $4,8 \%$ pela PCR. Na análise estatística descritiva dos dados verificou-se que houve uma maior frequência de cães positivos machos, acima de dois anos, com raça definida, provenientes de área rural, domiciliados e com a presença de carrapatos. Conclui-se que independente do tipo de fator de risco, a babesiose encontra-se disseminada em Recife, Pernambuco e sua prevalência não variou em relação à maioria das regiões do Brasil. A PCR demonstrou ser um exame sensível frente ao parasitológico sanguíneo, devendo ser introduzida na rotina clínica.
\end{abstract}

Palavras-chave: Babesiose, cães, diagnóstico molecular, infecção

\section{Introduction}

Babesia spp. is an intraerythrocytic protozoan that infects numerous vertebrate hosts, and may cause diseases in many pets and wild animals as well as in humans (BRANDÃO; HAGIWARA, 2002). Babesiosis is a disease that occurs primarily in tropical and subtropical regions (CARRET et al., 1999). It is associated with severe and fatal symptoms, and is transmitted via ticks.

Babesia canis vogeli infection is endemic in Brazil (PASSOS et al., 2005; DUARTE et al., 2008). In addition, there were reports describing the presence of Babesia gibsoni in Paraná (TRAPP et al., 2006a; JOJIMA et al., 2008). A study has also identified Babesia canis rossi in the Federal District Brasília (VASCONCELOS, 2010). The geographic distribution of babesiosis is greatly dependent on the habitat of its carrier, the ticks. Knowledge on the prevalence and clinical pathological conditions caused by different Babesia species all over the world is of great epidemiological and medical interest (SOLANO-GALLEGO; BANETH, 2011).

Diagnosis for babesiosis is based on anamnesis and physical examinations. Additionally, several intraerythrocytic stages of Babesia spp. can be observed inside the erythrocytes using Giemsastained peripheral blood smears (GUIMARÃES et al., 2002). Nevertheless, a limiting factor for classification of Babesia infection stems from the similarities between different species and subspecies (KJEMTRUP et al., 2000; JEFFERIES et al., 2007).

As there are variations in the pathogenesis and clinical manifestations among the Babesia species and subspecies in dogs, an accurate diagnosis will provide valuable insights on its distribution, which will be important for therapeutic options and epidemiological studies (IONITA et al., 2012). Molecular tests, in particular, polymerase chain reaction (PCR), have been increasingly used in epidemiological studies (BIRKENHEUER et al., 2004; JOJIMA et al., 2008; SILVA et al., 2012).

Little is known about the possible risk factors associated with canine babesiosis in Brazil (DANTAS-TORRES; FIGUEREDO, 2006). Therefore, due to the importance of this disease for small animal veterinary practice, the aim of this work was to determine the occurrence of Babesia canis vogeli in dogs from Recife, Pernambuco, through molecular detection and parasitological tests. In addition, we were also interested in evaluating the risk factors associated with this disease. 


\section{Materials and Methods}

A total of 146 dogs of both sexes, varied breeds and ages, coming from clinical centers in the Veterinary School Hospital of Recife, Pernambuco, were evaluated. They showed clinical signs of babesiosis such as lethargy, vomit, anorexia, fever, weakness, mucosal pallor, jaundice, splenomegaly, hematuria (GUIMARÃES et al., 2002, 2004; BASTOS et al., 2004), dehydration, weight loss, abdominal pain, and sensitivity to renal palpation (BASTOS et al., 2004).

This research was approved by the Ethics Committee in the Use of Animals (CEUA) under the decision number 031/2012-1506/2011-B05. The epidemiological analysis used in this work was based on a previous cross-sectional study (CÔRTES, 1993). Sample size for determining disease prevalance was based on an expected prevalence of $28.7 \%$ for Babesia spp. infection (COSTA-JÚNIOR et al., 2009), which required a minimum of 79 dogs. A confidence interval of $95 \%$ and statistical error of $10 \%$ were used for statistical analysis (THRUSFIELD, 2004). Analysis was performed using the Win Episcope 2.0 software, taking into account the disease prevalence, confidence interval, and statistical errors mentioned above.

With permission from the dog owner we conducted interviews using specific forms with epidemiological and clinical data. Blood collection was performed via external jugular venous puncture using disposable syringes. Blood $(2 \mathrm{~mL})$ was collected and placed in EDTA-K3-containing Vacutainer ${ }^{\circledR}$ plastic tubes. Hemoparasite detection was performed by optical microscopy on three blood smear slides. The remaining blood $(0.5 \mathrm{~mL})$ was stored at $-80^{\circ} \mathrm{C}$ prior to molecular diagnosis by DNA extraction and subsequent PCR.

DNA was extracted from each $200 \mu \mathrm{L}$ blood sample (in EDTA) with the DNeasy Blood and Tissue kit (Qiagen ${ }^{\mathrm{TM}}-\mathrm{USA}$ ) according to the manufacturer instructions. Extracted DNA was placed in sterile $1.5 \mathrm{~mL}$ polypropylene tubes, labeled accordingly, and stored at $-20^{\circ} \mathrm{C}$ prior to DNA amplification.

The oligonucleotide primers used for PCR detection of $B$. canis vogeli amplified an approximately 590 base pairs (bp) region in the gene, as described by Duarte et al. (2008). The sense primer BAB1 (5'-GTG AAC CTT ATC ACT TAA AGG-3') was specific for a conserved region in the 18S rRNA gene of Babesia spp., and the antisense BAB4 (5'-CAA CTC CTC CAC GCA ATC G-3') was specific for a region in the rRNA large subunit of Babesia canis vogeli. The amplification protocol was as follows: initial denaturation at $94^{\circ} \mathrm{C}$ for $2 \mathrm{~min}$; followed by 35 cycles at $94^{\circ} \mathrm{C}$ for $30 \mathrm{~s}$, $56^{\circ} \mathrm{C}$ for $30 \mathrm{~s}$, and $72^{\circ} \mathrm{C}$ for $1 \mathrm{~min}$; final extension was carried out at $72^{\circ} \mathrm{C}$ for $5 \mathrm{~min}$ (OGLIARI et al., 2000).

Amplification reaction of the DNA samples were performed in $200 \mu \mathrm{L}$ microtubes with a final volume of $12.5 \mu \mathrm{L}$. Reaction mixture contained $0.5 \mu \mathrm{M}$ of each primer $(20 \mathrm{pM} / \mathrm{mL})$ as well as the mastermix containing $200 \mu \mathrm{M}$ dNTP, $1.5 \mathrm{mM} \mathrm{MgCl}, 5 \mathrm{U}$ Taq DNA polymerase (Taq PCR Master Mix - QIAGEN/ USA), $2.5 \mu \mathrm{L}$ DNA (genomic DNA at an average concentration of $200 \mathrm{ng} / \mu \mathrm{L}$ ), and $2.75 \mu \mathrm{L}$ Milli-Q ultrapure water. Amplification reactions were carried out in a thermocycler (XP Thermal Cycler - Bioxer Technology CO. LTD). Mili-Q ultrapure water was used as negative control, and positive control for Babesia canis vogeli was obtained from infected dog samples provided by the Laboratory of Parasitic Diseases of Domestic Animals of the Federal Rural University of Pernambuco.

Analysis of the amplified product was performed by electrophoresis on a $1.5 \%$ agarose gel with $1 \times$ TAE running buffer (TRIS- acetate EDTA, $\mathrm{pH}$ 8.0), and ran at a constant voltage of 6-7 V/cm. A $100 \mathrm{bp}$ molecular weight marker was used for quantification of product size. Samples were stained with Blue Green (LGC Biotecnologia, Brazil), and were subsequently imaged under ultraviolet light using a gel-imaging system (Camera Kodak Digital DC/120 Zoom). 
Descriptive statistics analysis was used to calculate the relative and absolute frequency of the variables of interest. To identify the risk factors associated with Babesia canis vogeli infection, we performed univariate analysis of variables via the Pearson's chi-square test, and when necessary, the Fisher's exact test. The Epi Info 7.0 software was used for statistical analysis, and the Kappa coefficient was calculated to evaluate the concordance between hemoparasites detection and PCR results. The independent and explanatory variables considered in the model were those that showed statistical significance of $<0.20$. This probability was defined to include all possible risk factors of the disease in the analysis (HOSMER; LEMESHOW, 1989).

\section{Results and Discussion}

According to our PCR results, the percentage of Babesia canis vogeli infection in dogs was $4.8 \%$. However, Silva et al. (2012) examined 300 dogs in São Luís, Maranhão using PCR, and detected a Babesia canis vogeli infection rate of $3.3 \%$. This difference may be because the population used in this study comprised mostly of animals with symptoms of babesiosis, which differed from the previous study.

In Brazil, O’Dwyer et al. (2009) observed that dogs from the countryside in the state of São Paulo had a Babesia spp. infection rate of $8 \%$. Ramos et al. (2010) detected 7.31\% positive cases for Babesia canis vogeli in dogs from Pernambuco using PCR, and Jojima et al. (2008) observed amplification of Babesia spp. DNA in $37.2 \%$ of 282 samples in Londrina, Paraná.

From the blood parasitological examinations, we observed that $1.4 \%$ of the animals analyzed were positive for Babesia spp. Numerous parasitological investigations in Brazil showed that the prevalence of infection by Babesia spp. varies. In a retrospective study performed in Bahia by Ungar de Sá et al. (2007) with 7,243 blood samples, the authors observed that 2,459 (33.95\%) samples were positive for Babesia spp. On the other hand, Bastos et al. (2004) in Minas Gerais observed Babesia spp. infection in 31.4\% of the dogs examined, and O'Dwyer et al. (2001) found Babesia spp. in blood smears of 5.2\% dogs from the rural areas of Rio de Janeiro.

The results from the parasitological tests in this study were similar to those reported by Miranda et al. (2008) in Campos dos Goytacazes, Rio de Janeiro, in which $1.47 \%$ of the 2,031 dogs analyzed were infected by Babesia spp. It is known that blood smear technique has high specificity. However, it also has low sensitivity due to the variable nature of parasitemia, thus hindering the visualization of infected circulating erythrocytes. As a result, nondetection of the parasite in blood parasitological tests does not necessary mean absence of infection (MASUDA, 1983).

The Kappa test showed low concordance between the presence of merozoites in the blood smears $(1.4 \%$; 2 positive dogs of 146 tested) and results from conventional PCR for $B$. canis vogeli. (Kappa $=0.147$, Concordance $=0.500$ ). The low concordance value may be due to low parasitemia; the animals tested positive for the disease may have been in the chronic phase of the disease, where parasitemia is usually low. In addition, discrepancy between the two results may also be due to differences in sensitivities between these laboratory techniques.

In blood parasitological tests, we also observed that $6.2 \%$ of the dogs were positive for Ehrlichia spp., 9.5\% for Anaplasma platys, but no coinfections were observed. Co-infections by $A$. platys and $E$. canis have been reported in several regions of Brazil such as Ribeirão Preto, São Paulo (SANTOS et al., 2009), and Cuiabá (SOUSA et al., 2009), as well as other countries such as China (HUA et al., 2000) and Venezuela (SUKSAWAT et al., 2001). Simultaneous infections by Babesia canis vogeli and Anaplasma platys were observed in Australia by Brown et al. (2006). These co-infections are common, and it was suggested that the same vectors 
Rhipicephalus sanguineus of E. canis and Babesia canis vogeli are responsible for the transmission of Anaplasma platys (YABSLEY et al., 2008).

Table 1 depicts the data analysis on the risk factors associated with Babesia canis vogeli infection. Through logistic regression analysis, none of the variables was found to be a risk factor. With regard to the sex, males were more likely to be affected as compared to females, despite the fact that we did not find any significant statistical differences between the two. This was in agreement with the findings by Jojima et al. (2008) in Londrina, Paraná, who also observed higher diagnosis percentages of Babesia spp. infection in males (22\%; obtained by PCR). There were no reports alluding to the differences in Babesia spp. infection rate based on a specific sex or breed in the literature (GUIMARÃES et al., 2002; BASTOS et al., 2004; TRAPP et al., 2006b).

We observed higher frequencies of positive diagnosis in animals aged two years or older. Similarly, Trapp et al. (2002) observed higher seroprevalence in dogs older than one year of age at a hospital in the North of Paraná. However, Brown et al. (2006) observed that puppies were more severely affected by babesiosis, and Jojima et al. (2008) detected higher percentage of positive cases for babesiosis in dogs between one and five years of age.

In a study conducted with dogs in rural areas in semiarid regions of Brazil, no correlation was observed between seroprevalence of infection and age or sex of the animals. However, mixed breeds presented higher rates of infection when compared with that of pure breeds (MAIA et al., 2007). This was in contrast with the results obtained in our study, where most infected dogs were of a defined breed.

These differences may have occurred because of the diagnostic techniques used, the specific population in the study, and climatic factors from both locations where the research was being conducted. Costa-Júnior et al. (2009) observed that seroprevalence of Babesia canis vogeli infection was directly related to the age of the animals as well as tick infestation; the older the animal, the higher the seroprevalence. These animals may have a greater probability for chronic infection, which facilitates the occurrence of the disease.

Results indicated that purebred animals had higher frequencies of infection, in particular Pinscher (75\%) and Pitbull (25\%). However, this difference did not reach statistical significance $(\mathrm{p}>0.05)$. On the other hand, Jojima et al. (2008) observed that babesiosis was more prevalent in dogs with of mixed breed, followed by German Shepherd (3.9\%), Poodle (3.5\%), Rottweiler (1.8\%), and $(11 \%)$ other breeds. Several studies in Brazil did not observe predisposition of specific breeds to canine babesiosis (GUIMARÃES et al., 2002; BASTOS et al., 2004; TRAPP et al., 2006b). Costa-Júnior et al. (2009) evaluated dogs in the rural area of Minas Gerais, and observed that neither breed nor sex was a risk factor for seroprevalence of $B$. canis vogeli.

We found that dogs with access to outside environment, fed home-made food, from a rural area, raised inside the house, and acess to the outside environment were most affected by babesiosis, although no significant difference was observed between these conditions. In the case of diseases transmission, dogs raised inside the house were infected when in contact with ticks, i.e., $R$. sanguineus, which may also live in the houses (NEER; HARRUS, 2006). In Brazil, Babesia canis vogeli was characterized in the urban area by Passos et al. (2005). Ribeiro et al. (1990) detected the presence of Babesia canis in $66.9 \%$ of dogs from the urban area, and O'Dwyer et al. (2001) observed $5.2 \%$ Babesia spp. infection in dogs from rural areas using blood parasitological tests. 
Table 1. Analysis of risk factors associated with Babesia canis vogeli infection in dogs from Recife, Pernambuco.

\begin{tabular}{|c|c|c|c|c|}
\hline Variable & $\mathbf{N}$ & $\begin{array}{c}\text { PCR } \\
\text { Positive }\end{array}$ & $\begin{array}{c}\text { Univariate analysis } \\
\text { OR (CI 95 \%) }\end{array}$ & P Value \\
\hline \multicolumn{5}{|l|}{ Sex } \\
\hline Male & 74 & $4(5.4 \%)$ & \multirow{2}{*}{$1.31(0.21-9.28)$} & \multirow{2}{*}{0.515} \\
\hline Female & 72 & $3(4.2 \%)$ & & \\
\hline \multicolumn{5}{|l|}{ Age } \\
\hline$<6$ months & 24 & - & - & \multirow{3}{*}{0.165} \\
\hline Between 6 months to 2 years & 24 & - & - & \\
\hline Above 2 years & 98 & $7(7.1 \%)$ & - & \\
\hline \multicolumn{5}{|l|}{ Breed } \\
\hline Without defined breed & 101 & $4(4.0 \%)$ & \multirow{2}{*}{$0.57(0.09-4.13)$} & \multirow{2}{*}{0.370} \\
\hline With defined breed & 45 & $3(6.7 \%)$ & & \\
\hline \multicolumn{5}{|l|}{ Access to outside environment } \\
\hline Yes & 77 & $3(3.9 \%)$ & \multirow{2}{*}{$0.66(0.09-4.06)$} & \multirow{2}{*}{0.438} \\
\hline No & 69 & $4(5.8 \%)$ & & \\
\hline \multicolumn{5}{|l|}{ Diet } \\
\hline Pet food & 69 & $3(4.3 \%)$ & - & \multirow{3}{*}{0.929} \\
\hline Home-made food & 15 & $1(6.7 \%)$ & $1.57(0.03-2.17)$ & \\
\hline Mixed (Pet food + Home-made food) & 62 & $3(4.8 \%)$ & $0.71(0.05-40.01)$ & \\
\hline \multicolumn{5}{|l|}{ Area where the animals live } \\
\hline Rural area & 54 & $3(5.6 \%)$ & \multirow{2}{*}{$1.29(0.18-7.96)$} & \multirow{2}{*}{0.514} \\
\hline Urban area & 92 & $4(4.3 \%)$ & & \\
\hline \multicolumn{5}{|l|}{ Raised indoors } \\
\hline Yes & 52 & $3(5.8 \%)$ & \multirow{2}{*}{$1.37(0.19-8.48)$} & \multirow{2}{*}{0.482} \\
\hline No & 94 & $4(4.3 \%)$ & & \\
\hline \multicolumn{5}{|l|}{ Type of garden } \\
\hline With cemented floor & 52 & $2(3.8 \%)$ & - & \multirow{4}{*}{0.957} \\
\hline Soil + Cemented floor & 76 & $4(5.3 \%)$ & - & \\
\hline Soil & 1 & $1(6.3 \%)$ & - & \\
\hline Without garden (apartment) & - & - & - & \\
\hline \multicolumn{5}{|l|}{ Typo of habit } \\
\hline Domiciled & 140 & $7(5.0 \%)$ & & \multirow{2}{*}{0.740} \\
\hline Semi-domiciled & 6 & - & - & \\
\hline \multicolumn{5}{|l|}{ Presence of Rhipicephalus sanguineus } \\
\hline Yes & 81 & $7(8.6 \%)$ & \multirow{2}{*}{ - } & \multirow{2}{*}{$0.014 *$} \\
\hline No & 65 & - & & \\
\hline Presence of fleas & & & & \\
\hline Yes & 30 & $2(6.7 \%)$ & $158(0.14-10.28)$ & 0.440 \\
\hline No & 116 & $5(4.3 \%)$ & $1.58(0.14-10.28)$ & 0.440 \\
\hline Infestation by ticks & & & & \\
\hline Yes & 135 & $7(5.2 \%)$ & - & 0570 \\
\hline No & 11 & - & - & $0.5 / 0$ \\
\hline
\end{tabular}

This demonstrates that in the case of vectors found in either the house, the pet shops, hemoparasites, regardless of the animal's access to or other locations where ticks are present. Results different environments, or whether they are raised from this study suggest that animals from the urban in rural or urban areas, dogs may be infected by and rural environments have equal chances of 
acquiring the infection, as no significant difference in infection was observed between animals from different environments. Silva et al. (2012) observed that among the $31.67 \%$ of dogs infested by ticks, $14 \%$ were from an urban area, whereas $17.67 \%$ were from the rural area, with $R$. sanguineus being the only species of tick detected in both areas. No correlation was detected between the presence of Babesia canis vogeli and the animal's area of origin.

With regard to the type of ectoparasites, we observed that fleas infected $6.7 \%$ of the dogs, and that babesiosis in dogs was significantly associated with the presence of $R$. sanguineus. However, in the logistic regression analysis, this variable was not confirmed to be a risk factor. Climatic conditions directly influence the population dynamics of ticks, thus affecting the transmission of Babesia spp. and consequently its permanence in the environment (FRIEDHOFF, 1988). The R. sanguineus species of tick has nidicolous habits, which means that it spends its free-living stage in houses or resting locations of their host (SILVA et al., 2012).

\section{Conclusion}

We conclude that regardless the type of risk factor, babesiosis is found disseminated in Recife, Pernambuco, and its prevalence does not vary in most regions of Brazil. PCR was shown to be a sensitive test in detecting the presence of this parasite when compared to blood parasitological tests, and thus, should be included in future clinical routines.

\section{Acknowledgments}

We would like to acknowledge FACEPE for granting the $\mathrm{PhD}$ scholarship and financial support, which was essential for this work. We would also like to acknowledge Professor Leucio Camara Alves from the Department of Veterinary Medicine of the Federal Rural University of Pernambuco, for providing the positive control for the Babesia canis vogeli tests.

\section{References}

BASTOS, C. V.; MOREIRA, S. M.; PASSOS, L.M.F. Retrospective study (1998-2001) on canine babesiosis in Belo Horizonte, Minas Gerais, Brazil. Annais New York Academy of Sciences, New York, n. 1026, p. 158-160, 2004.

BIRKENHEUER, A. J.; NEEL, J.; RUSLANDER, D.; LEVY, M. G.; BREITSCHWERDT, E. B. Detection and molecular characterization of a novel large Babesia species in a dog. Veterinary Parasitology, Amsterdam, v. 124, n. 3-4, p. 151-160, 2004.

BRANDÃO, L. P.; HAGIWARA, M. K. Revisão: Babesiose canina. Revista Clínica Veterinária, Guará, Ano 7, n. 41, p. 50-59, nov./dez. 2002.

BROWN, G. K.; CANFIELD, P. J.; DUNSTAN, R. H.; ROBERTS, T. K.; MARTIN, A. R.; BROWN, C. S.; IRVING, R. Detection of Anaplasma platys and Babesia canis vogeli and their impact on platelet numbers in free-roaming dogs associated with remote Aboriginal communities in Australia. Australian Veterinary Journal, New Zealand, v. 84, n. 9, p. 321-325, sept. 2006.

CARRET, C.; WALAS, F.; CARCY, B.; GRANDE, N.; PRÉCIGOUT, E.; MOUBRI, K.; SCHETTERS, T. P.; GORENFLOT, A. Babesia canis canis, Babesia canis vogeli, Babesia canis rossi: differentiation of the three subspecies by a restriction fragment length polymorphism analysis on amplified small subunit ribosomal RNA genes. The Journal of Eukaryotic Microbiology, v. 46, n. 3, p. 298-303, 1999.

CÔRTES, J. A. Epidemiologia: conceitos e principais fundamentos. São Paulo: Varela, 1993. 43 p.

COSTA-JÚNIOR, L. M.; RIBEIRO, M. F. B.; REMBECK, K.; RABELO, E. M. L.; ZAHLERRINDER, M.; HIRZMANN, J.; PFISTER, K.; PASSOS, L. M. F. Canine babesiosis caused by Babesia canis vogeli in rural areas of the State of Minas Gerais, Brazil and factors associated with its seroprevalence. Research in Veterinary Science, Oxford, v. 86, p. 257-260, 2009.

DANTAS-TORRES, F.; FIGUEREDO, L. A. Canine babesiosis: a Brazilian perspective. Veterinary Parasitology, Amsterdam, v. 141, n. 3-4, p. 197-203, 2006.

DUARTE, S. C.; LOULY, C. C. B.; SILVEIRA NETO, O. J.; ROMANOWSKI, T. N. A.; LINO JUNIOR, R. S.; LINHARES, G. F. C. Diagnóstico parasitológico e molecular da babesiose canina na cidade de Goiânia-Go. Revista de Patologia Tropical, Goiânia, v. 37, n. 3, p. 229-236, jul./set. 2008. 
FRIEDHOFF, K. T. Transmission of Babesia. In: RISTIC, M. Babesiosis of domestic 5 animals and man. Boca Raton: CRC Press, 1988. p. 23-52.

GUIMARÃES, A. M.; OLIVEIRA, T. M. F. S.; SANTA ROSA, I. C. A. Babesiose canina: uma visão dos clínicos veterinários de Minas Gerais. Revista Clínica Veterinária, São Paulo, Ano 8, n. 41, p. 60-68, 2002.

GUIMARÃES, J. C.; ALBERNAZ, A. P.; MACHADO, J. A.; JÚNIOR, O. A. M.; GARCIA, L. N. N. Aspectos clínico-laboratoriais da babesiose canina na cidade de Campos do Goytacazes, RJ. Revista Brasileira de Parasitologia Veterinária, Jaboticabal, v. 13, p. 229, 2004. Suplemento 1.

HOSMER, D. W.; LEMESHOW, S. Applied logistic regression. New York: JohnWiley \& Sons, 1989. 241 p.

HUA, P.; YUHAI, M.; SHIDE, T.; YANG, S.; BOHAI, W.; XIANGRUI, C. Canine ehrlichiosis caused simultaneously by Ehrlichia canis and Ehrlichia platys. Microbiology and Immunology, Stanford, v. 44, n. 9, p. 737-739, 2000.

IONITA, M.; MITREA, I. L.; PFISTER, K.; HAMEL, D.; BUTATU, C. M.; SILAGHI, C. Canine babesiosis in Romania due to Babesia canis and Babesia vogeli: a molecular approach. Parasitology Research, Berlin, v. 110, n. 5, p. 1659-1664, 2012.

JEFFERIES, R.; RYAN, U. M.; JARDINE, J.; BROUGHTON, D. K.; ROBERTSON, I. D.; IRWIN, P. J. Blood, Bull Terriers and Babesiosis: further evidence for direct transmission of Babesia gibsoni in dogs. Australian Veterinary Journal, New Zealand, v. 85, n. 11, p. 459-463, 2007.

JOJIMA, F. S.; GARCIA, J. L.; VIDOTTO, M. C.; BALARIN, M. R. S.; FABRETTI, A. K.; GASPARINI, M. R.; COELHO, A. L. M.; VIDOTTO, O. Ocorrência e caracterização molecular de espécies de Babesia em cães de uma população hospitalar da região de Londrina, PR. Revista Brasileira de Parasitologia Veterinária, Jaboticabal, v. 17, p. 277-283, 2008. Suplemento 1.

KJEMTRUP, A. M.; KOCAN, A. A.; WHITWORTH, J.; MEINKOTH, A. J.; BIRKENHEUER, A. J.; CUMMINGS, J.; BOUDREAUX, M. K.; STOCKHAM, S. L; IRIZARRY-ROVIRA, A.; CONRAD, P. A. There are at least three genetically distinct small piroplasms from dogs. International Journal for Parasitology, Oxford, v. 30, n. 14, p. 1501-1505, 2000.

MASUDA, T. Relapse of canine babesiosis after prednisolone treatment. Modern Veterinary Practice, Santa Barbara, v. 64, n. 11, p. 931-932, 1983.

MAIA, M. G.; COSTA, R. T.; HADDAD, J. P. A.; PASSOS, L. M. F.; RIBEIRO, M. F. B. Epidemiological aspects of canine babesiosis in the semiarid area of the state of Minas Gerais, Brazil. Preventive Veterinary Medicine, Amsterdam, v. 79, n. 2-4, p. 155-162, 2007.

MIRANDA, F. J. B.; ALBERNAZ, A. P.; MELO JÚNIOR, O. A.; MACHADO, J. A. Frequência de cães infectados por Babesia spp. em Campos dos Goytacazes, RJ. Ciência Animal Brasileira, Goiânia, v. 9, n. 1, p. 238241, jan./mar. 2008.

NEER, M.; HARRUS, S. Ehrlihiosis, neoricketsiosis, anaplasmosis and wolbachia infection. In: GREENE, C. E. Infectious diseases of dog and cat. $3^{\text {th }}$ ed. St Louis: Saunders, 2006. n. 28, p. 203-232.

O’DWYER, L. H.; LOPES, V. V. A.; RUBINI, A, S.; PADUAN, K. S.; RIBOLlA, P. E. M. Babesia spp. infection in dogs from rural areas of São Paulo State, Brazil. Revista Brasileira de Parasitologia Veterinária, Jaboticabal, v. 18, n. 2, p. 23-26, 2009.

O'DWYER, L. H.; MASSARD, C. L.; SOUZA, J. C. P. Hepatozoon canis infection associated with dog ticks of rural areas of Rio de Janeiro State, Brazil. Veterinary Parasitology, Amsterdam, v. 94, n. 3, p. 143-150, 2001.

OGLIARI, J. B.; BOSCARIOL, R. L.; CAMARGO, L. E. A. Optimization of PCR amplification of maize microsatellite loci. Genetics and Molecular Biology, Ribeirão Preto, v. 23, n. 2, p. 395-398, 2000.

PASSOS, L. M.; GEIGER, S. M.; RIBEIRO, M. F.; PFISTER, K.; ZAHLER-RINDER, M. First molecular detection of Babesia vogeli in dogs from Brazil. Veterinary Parasitology, Amsterdam, v. 127, n. 1, p. 8185, 2005.

RAMOS, R.; RAMOS, C.; ARAÚJO, F.; OLIVEIRA, I.; PIMENTEL, D.; GALINDO, M.; SANTANA, M.; ROSAS, E.; FAUSTINO, M.; ALVES, L. Molecular survey and genetic characterization of tick-borne pathogens in dogs in metropolitan Recife (north-eastern Brazil). Parasitology Research, Berlin, v. 107, n. 5, p. 1115-1120, 2010.

RIBEIRO, M. F. B.; LIMA, J. D.; PASSOS, L. M. F.; GUIMARÃES, A. M. Frequência de anticorpos fluorescentes anti-Babesia canis em cães de Belo Horizonte, Minas Gerais. Arquivo Brasileiro de Medicina Veterinária e Zootecnia, Belo Horizonte, v. 42, n. 6, p. 511-517, 1990.

SANTOS, F.; COPPEDE, J. S.; PEREIRA, A. L.; OLIVEIRA, L. P.; ROBERTO, P. G.; BENEDETTI, R. B.; ZUCOLOTO, L. B.; LUCAS, F.; SOBREIRA, L.; MARINS, M. Molecular evaluation of the incidence of Ehrlichia canis, Anaplasma platys and Babesia spp. in dogs from Ribeirão Preto. Veterinary Journal, London, v. 179 , n. 1 , p. 145-148, jan. 2009. 
SILVA, A. B.; COSTA, A. P.; SÁ, J. C.; COSTA, F. B.; SANTOS, A. C. G.; GUERRA, R. M. S. N. C. Detecção molecular de Babesia canis vogeli em cães e em Rhipicephalus sanguineus na mesorregião do Oeste Maranhense, Nordeste Brasileiro. Ciência Animal Brasileira, Goiânia, v. 13, n. 3, p. 388-395, jul./set. 2012.

SOLANO-GALLEGO, L.; BANETH, G. Babesiosis in dogs and cats-expanding parasitological and clinical spectra. Veterinary Parasitology, Amsterdam, v. 181, n. 1, p. 48-60, 2011.

SOUSA, V. R. F.; BOMFIM, T. C. B.; ALMEIDA, A. B. P. F.; BARROS, L. A.; SALES, K. G.; JUSTINO, C. H. S.; DALCIN, L. Coinfecção por Anaplasma platys and Ehrlichia canis in dogs diagnosed by PCR. Acta Scientiae Veterinariae, Porto Alegre, v. 37, n. 3, p. 281-283, 2009.

SUKSAWAT, J.; PITULLE, C.; ARRAGAALVARADO, C.; MADRIGAL, K.; HANCOCK, S. I.; BREITSCHWERDT, E. B. Coinfection with three Ehrlichia species in dogs from Thailand and Venezuela with emphasis on consideration of $16 \mathrm{~S}$ ribosomal DNA secondary structure. Journal of Clinical Microbiology, Barcelona, v. 39, n. 1, p. 90-93, 2001.

TRAPP, S. M.; MESSICK, J. B.; VIDOTTO, O.; JOJIMA, F. S.; MORAIS, H. S. M. Babesia gibsoni genotype Asia in dogs from Brazil. Veterinary Parasitology, Amsterdam, v. 141, n. 1-2, p. 177-180, 2006 a.

TRAPP, S. M.; DAGNONE, A. S.; VIDOTTO, O.; FREIRE, R. L.; AMUDE, A. M.; MORAIS, H. S. A. Seroepidemiology of canine babesiosis and ehrlichiosis in a hospital population. Veterinary Parasitology, Amsterdam, v. 140, n. 3-4, p. 223-230, 2006 b.
TRAPP, S. M.; DAGNONE, A. S.; VIDOTTO, O.; FREIRE, R. L.; MORAIS, H. S. M. de. Seroepidemiology of canine babesiosis and ehrlichiosis in a hospital population in south Brazil. Journal of Veterinary Internal Medicine, Ohio, v. 16, n. 3, p. 365, 2002.

THRUSFIELD, M. Epidemiologia veterinária. 2. ed. Cambridge: Blackwell Science, 2004. 479 p.

UNGAR DE SÁ, M. F. M.; UNGAR DE SÁ, J. E.; BITTENCOURT, D. V. V.; BISPO, A. C.; RÉGIS, A. M. M.; SOUZA FILHO, N. J.; GOMES NETO, C. M. B.; SOUZA, B. M. P. S.; BITTENCOURT, T. C. C.; FRANKE, C. R. Estudo retrospectivo (1991-2005) dos casos de babesiose canina na cidade de Salvador e Região Metropolitana, Bahia. Revista Brasileira de Saúde e Produção Animal, Salvador, v. 8, n. 3, p. 178183, jul./set, 2007.

VASCONCELOS, M. F. Estudo da infecção por Babesia spp. em cães da região periurbana de Brasília, Distrito Federal. 2010. Dissertação (Mestrado em Saúde Animal) - Universidade de Brasília, Brasília.

YABSLEY, M. J.; MCKIBBEN, J.; MACPHERSON, C. N.; CATTAN, P. F.; CHERRY, N. A.; HEGARTY, B. C.; BREITSCHWERDT, E. B.; CONNOR, T. O.; CHANDRASHEKAR, R.; PATERSON, T.; PEREA, M. L.; BALL,G.; FIESEN, S.; GOEDDE, J.; HENDERSON, B.; SYLVESTER, W. Prevalence of Ehrlichia canis, Anaplasma platys, Babesia canis, Hepatozoon canis, Bartonella vinsonii berkhoffi, and Rickettsia spp. in dogs from Grenada. Veterinary Parasitology, Amsterdam, v. 151, n. 2-4, p. 279-285, feb. 2008. 
